\title{
PENGARUH BRAND IMAGE, BRAND AWARENESS, DAN KUALITAS PRODUK TERHADAP KEPUTUSAN PEMBELIAN PRODUK PLANET POPCORN PADA MAHASISWA FAKULTAS EKONOMI UNIVERSITAS TARUMANAGARA JAKARTA
}

\author{
Sanny Ekawati dan Yoga Aryadirda \\ Fakultas Ekonomi Universitas Tarumanagara \\ Email: ekawatysanny@yahoo.com
}

\begin{abstract}
This study was conducted to investigate the effect of brand image, brand awareness, and product quality on the consumer's purchase decision. The population of this research were students of Tarumanagara University in Jakarta. The sampling frame was limited to those of the Economic Faculty. The non-probabilistic convenience sampling method was used in this research. The method of data collection was conducted by distributing questionnaires to 100 respondents. The technique of data analysis used was the multiple regression analysis. The findings of this research showed that purchase decision is positively and significantly affected by brand image, brand awareness, and product quality.
\end{abstract}

\section{PENDAHULUAN}

Seiring dengan perkembangan bisnis saat ini telah melahirkan banyak inovasi baru yang dapat kita temukan dalam berbagai produk. Konsumen menuntut suatu produk yang sesuai dengan minat, kepentingan dan daya beli mereka serta akan melakukan tindakan yang lebih selektif dalam memenuhi kebutuhan mereka. Menurut Kotler dan Keller (2006), perusahaan dalam memenangkan persaingan harus menampilkan produk terbaik dan dapat memenuhi minat konsumen yang selalu berkembang dan berganti.

Produk makanan ringan merupakan produk yang tumbuh pesat di Indonesia. Berbagai variasi produk serta cara penyajian cukup banyak ditemukan di pasaran. Salah satunya yaitu produk popcorn. Saat ini cakupan minat popcorn semakin luas. Popcorn yang awalnya hanya dijual di bioskop, saat ini sudah mulai dapat ditemukan di berbagai tempat perbelanjaan. Semakin meningkatnya minat masyarakat terhadap popcorn membuat banyak merek popcorn muncul di pasaran.

Menurut Wicaksono dalam Sulistyawati (2011) serta Nigam dan Kaushik (2011) telah mengemukakan pentingnya pengembangan citra merek dan kualitas produk serta kesadaran merek dalam keputusan pembelian. Menurut Kotler dan Armstrong (2008), keputusan pembelian adalah membeli merek yang paling disukai, tetapi dua faktor bisa berada antara niat pembelian dan keputusan pembelian. Faktor pertama adalah sikap orang lain dan faktor kedua adalah faktor situasional yang tidak diharapkan.

Dari definisi di atas menjelaskan bahwa keputusan pembelian yang terjadi pada suatu produk dipengaruhi oleh citra merek, kesadaran merek, dan kualitas produk.

Menurut Wilson Arafat (2006), brand image adalah persepsi terhadap merek yang direfleksi oleh asosiasi merek dalam memori konsumen yang mengandung makna bagi konsumen".

Dari definisi di atas menjelaskan bahwa hendaknya upaya membangun citra merek dilakukan oleh perusahaan dengan sebaik-baiknya agar konsumen dapat mengingat merek 
yang diperoleh dari kesan terhadap merek tersebut. Hal ini telah dilakukan oleh Planet Popcorn dimana citra merek sudah dibangun dengan baik dengan cara membuat website dan memiliki akun media sosial seperti Facebook.

Menurut Shimp (2010) : "Brand awareness is an issue of whether a brand name comes to mind when consumers think about a particular product category and the ease with which the name is evoked".

Dari definisi di atas menjelaskan bahwa kesadaran merek memperhatikan tentang kemampuan konsumen dalam mengenali merek. Hal ini sudah dilakukan oleh Planet Popcorn dengan cara membuka beberapa gerai di mall yang dibuat dengan menarik sehingga membuat konsumen menjadi tertarik untuk datang.

Menurut Kotler and Armstrong (2008) : "Product quality is the ability of a product to perform its function, it includes the product's several durability, realibility, precision, ease of operational repair, and other valued attributes".

Dari definisi di atas menunjukkan bahwa kualitas produk dipengaruhi oleh banyak faktor, seperti bahan yang dipakai untuk menambah kualitas produk Planet Popcorn dengan menggunakan bahan-bahan berkualitas tinggi yang sehat dengan rendah lemak dan rendah kalori. Hal ini sesuai dengan pernyataan Planet Popcorn terhadap produknya dalam menjaga kualitas produk sehingga menarik minat konsumen.

Permasalahan dalam penelitian ini sebagai berikut: (1) Apakah terdapat pengaruh brand image terhadap keputusan pembelian; (2) Apakah terdapat pengaruh brand awareness terhadap keputusan pembelian; (3) Apakah terdapat pengaruh kualitas produk terhadap keputusan pembelian;

Tujuan Penelitian: (1) Untuk mengetahui pengaruh brand image terhadap keputusan pembelian; (2) Untuk mengetahui pengaruh brand awareness terhadap keputusan pembelian; (3) Untuk mengetahui pengaruh kualitas produk terhadap keputusan pembelian.

\section{KAJAIN TEORI}

Keputusan Pembelian. Keputusan pembelian adalah tindakan dari konsumen untuk mau membeli atau tidak terhadap produk. Dari berbagai faktor yang mempengaruhi konsumen dalam melakukan pembelian suatu produk, biasanya konsumen selalu mempertimbangkan kualitas, harga dan produk yang sudah dikenal oleh masyarakat.

Menurut Kotler dan Armstrong (2008) keputusan pembelian adalah membeli merek yang paling disukai, tetapi dua faktor bisa berada antara niat pembelian dan keputusan pembelian. Faktor pertama adalah sikap orang lain. Faktor kedua adalah faktor situasional yang tidak diharapkan.

Menurut Schiffman dan Kanuk (2004) keputusan pembelian diartikan sebagai pemilihan dari dua atau lebih alternatif yang ada, artinya bahwa syarat seseorang dapat membuat keputusan haruslah tersedia beberapa alternatif pilihan.

Menurut Belch (2004) keputusan pembelian : "The result of a long, detailed process that include an extensive information search, brand comparisons dan evaluations, dand other activities”. Artinya adalah hasil dari proses yang panjang dan detil yang mencakup pencarian ekstensif informasi, perbandingan merek dan evaluasi, dan kegiatan lainnya.

Berdasarkan pengertian di atas dapat disimpulkan bahwa keputusan pembelian adalah tindakan yang dilakukan konsumen untuk melakukan pembelian sebuah produk. Oleh karena itu, pengambilan keputusan pembelian konsumen merupakan suatu proses 
pemilihan salah satu dari beberapa alternatif penyelesaian masalah dengan tindakan yang jelas. Setelah itu, konsumen dapat melakukan evaluasi pilihan dan kemudian dapat menentukan sikap yang akan diambil selanjutnya.

Brand Image. Menurut Wilson Arafat (2006), brand image adalah persepsi terhadap merek yang direfleksi oleh asosiasi merek dalam memori konsumen yang mengandung makna bagi konsumen. Menurut Kotler dan Armstrong (2008), citra merek adalah persepsi dan keyakinan yang dilakukan oleh konsumen, seperti tercermin dalam asosiasi yang terjadi dalam memori konsumen.

Menurut Suryani (2008), citra merek merepresentasikan keseluruhan persepsi konsumen terhadap merek yang terbentuk karena informasi dan pengalaman konsumen terhadap suatu merek. Berdasarkan pengertian di atas dapat disimpulkan bahwa citra merek adalah sekumpulan asosiasi yang dipersepsikan oleh konsumen terhadap merek tertentu dan dapat disampaikan melalui sarana informasi yang ada.

Menurut Schiffman dan Kanuk (2008), beberapa faktor pembentuk citra merek antara lain: (1) Kualitas atau mutu berkaitan dengan kualitas produk barang yang ditawarkan oleh produsen dengan merek tertentu; (2) Dapat dipercaya atau diandalkan, berkaitan dengan pendapat atau kesepakatan yang di bentuk oleh masyarakat tentang suatu produk yang dikonsumsi; (3) Kegunaan atau manfaat, yang terkait dengan fungsi dari suatu produk barang yang bisa dimanfaatkan oleh konsumen; (4) Pelayanan yang berkaitan dengan tugas produsen dalam melayani konsumennya; (5) Resiko berkaitan dengan besar kecilnya akibat atau laba dan rugi yang mungkin dialami oleh konsumen; (6) Harga dalam hal ini berkaitan dengan tinggi rendahnya atau banyak sedikitnya jumlah uang yang dikeluarkan konsumen untuk mempengaruhi jangka panjang; (7) Citra yang dimiliki oleh merek itu sendiri yaitu berupa pandangan kesepakatan dan informasi yang berkaitan dengan suatu merek dari produk tertentu.

Brand Awareness. Menurut Shimp (2010) "Brand awareness is an issue of whether a brand name comes to mind when consumers think about a particular product category and the ease with which the name is evoked”. Artinya adalah kesadaran merek merupakan kemampuan sebuah merek untuk muncul dalam benak konsumen ketika konsumen sedang memikirkan kategori produk tertentu dan seberapa mudahnya nama tersebut dimunculkan.

Menurut Aaker (2008), kesadaran merek adalah kemampuan konsumen untuk mengenali atau mengingat kembali bahwa sebuah merek merupakan bagian dari kategori produk tertentu. Menurut Ambadar dkk (2007), kesadaran merek adalah ukuran kekuatan eksistensi suatu merek di benak pelanggan yakni tingkat pengenalan konsumen terhadap merek. Berdasarkan pengertian di atas dapat disimpulkan bahwa kesadaran merek adalah kemampuan konsumen untuk mengenali atau mengingat kembali suatu merek dari suatu kategori produk tertentu.

Menurut Aaker (2008) tingkatan dalam kesadaran merek antara lain : (1) Tidak sadar merek (unaware of brand). Tingkat yang paling rendah. Pada tingkat ini, pelanggan sama sekali tidak mengenali merek yang disebutkan meskipun melalui alat bantu, seperti menunjukkan gambar atau menyebutkan nama merek tersebut; (2) Mengenali merek (brand recognition). Pada tingkat ini, pelanggan akan mengingat merek setelah diberikan bantuan dengan memperlihatkan gambar atau ciri-ciri tertentu; (3) Mengingat kembali merek (brand recall). Pada tingkat ini mencerminkan merek-merek yang dapat diingat pelanggan dengan baik tanpa bantuan; (4) Puncak pikiran (top of mind). Tingkat tertinggi 
dan posisi ideal bagi semua merek. Pada tingkat ini, pelanggan sangat paham dan mengenali elemen-elemen yang dimiliki sebuah merek. Pelanggan akan menyebutkan merek untuk pertama kali, saat ditanya mengenai suatu kategori produk.

Kualitas Produk. Menurut Kotler dan Armstrong (2008) mendefinisikan produk berarti kombinasi barang dan jasa yang ditawarkan perusahaan kepada para pelaku pasar sedangkan kualitas merupakan keseluruhan sifat dan karakter suatu produk atau jasa berdasarkan kemampuannya untuk menyatakan kepuasan atau kebutuhan secara tidak langsung. Menurut Griffin dan Ebert (2006) kualitas didefinisikan menciptakan kesesuaian untuk menawarkan fitur penggunaan yang diinginkan.

Menurut Laksana (2008) menyatakan kualitas terdiri dari sejumlah keistimewaan produk, yang dapat memenuhi keinginan pelanggan, dengan demikian akan memberikan kepuasan atas penggunaan produk.

Menurut Kotler dan Armstrong (2008) "Product quality is the ability of a product to perform its function, it includes the product's several durability, realibility, precision, ease of operational repair, and other valued attributes".

Berdasarkan pengertian di atas dapat disimpulkan bahwa kualitas produk adalah kemampuan suatu produk untuk memperlihatkan fungsinya, waktu kegunaan, daya tahan, kemudahan operasi dan perbaikan, dan nilai-nilai lainnya.

Menurut Kotler (2000, pada Sulistyawati, 2011) menyatakan bahwa pencapaian kualitas yang baik bagi suatu perusahaan dibutuhkan beberapa ukuran untuk merumuskan kebujakan mengenai kualitas produk yaitu : (1) Fungsi barang. Mempengaruhi kepuasan konsumen, maka harus memproduksi barang yang mutunya sesuai dengan fungsi serta kegunaannya, daya tahannya, peralatannya dan kepercayaannya; (2) Wujud luar seperti bentuk, warna dan susunannya. Bila wujud luar dari barang tersebut tidak menarik meskipun kualitas barangnya baik maka belum tentu konsumen tertarik; (3) Biaya barang. Pada umumnya biaya dan harga suatu barang akan dapat menentukan mutu suatu barang tersebut.

Keputusan Pembelian. Keputusan pembelian terjadi apabila konsumen merasa puas ketika mengkonsumsi suatu merek produk. Kepuasan tersebut dapat berasal dari citra merek yang baik, kesadaran merek yang tinggi, dan atau kualitas produk yang baik. Jika hal tersebut belum dilakukan maka perusahaan perlu memikirkan tahap-tahap untuk meningkatkan keputusan pembelian.

Menurut Kotler (2000, pada Sulistyawati, 2011) tahap-tahap yang dapat dilakukan perusahaan antara lain: (1) Pengenalan kebutuhan. Tahapan pertama keputusan pembeli, dimana konsumen menyadari suatu masalah atau kebutuhan; (2) Pencarian informasi. Konsumen ingin mencari informasi lebih banyak, konsumen mungkin hanya memperbesar perhatian atau melakukan pencarian informasi secara aktif; (3) Evaluasi alternatif. Konsumen menggunakan informasi untuk mengevaluasi merek alternatif dalam sekelompok pilihan; (4) Keputusan pembelian. Keputusan pembeli tentang merek mana yang dibeli; (5) Perilaku pasca pembelian. Konsumen mengambil tindakan selanjutnya setelah pembelian, berdasarkan kepuasan mereka atau ketidakpuasan mereka.

Hipotesis. Keterkaitan Brand image terhadap Keputusan pembelian. Menurut penelitian yang dilakukan oleh Sulistyawati (2011) mengemukakan pentingnya pengembangan citra merek dalam keputusan pembelian. Brand image yang dikelola 
dengan baik akan menghasilkan konsekuensi yang positif, seperti meningkatkan pemahaman terhadap aspek-aspek perilaku konsumen dalam mengambil keputusan pembelian dan memperkaya orientasi konsumsi tehadap hal-hal yang bersifat simbolis lebih dari fungsi-fungsi produk. Dari penelitian yang telah dilakukan sebelumnya, maka dalam penelitian ini diusulkan hipotesis sebagai berikut :

H1: brand image berpengaruh positif terhadap keputusan pembelian

Keterkaitan Brand awareness terhadap Keputusan pembelian. Menurut penelitian yang dilakukan oleh Nigam dan Kaushik (2011), kesadaran merek memiliki peran penting dalam keputusan pembelian. Kesadaran merek perlu dilakukan agar konsumen mampu untuk mengenali atau mengingat suatu merek dari produk tertentu sehingga dalam pikiran konsumen akan memutuskan untuk melakukan pembelian. Ketika konsumen sudah menyadari suatu merek, maka kemungkinan untuk melakukan pembelian menjadi tinggi. Dari penelitian yang telah dilakukan sebelumnya, maka dalam penelitian ini diusulkan hipotesis sebagai berikut.

H2: brand awareness berpengaruh positif terhadap keputusan pembelian

Keterkaitan Kualitas produk terhadap Keputusan pembelian. Menurut penelitian yang dilakukan oleh Sulistyawati (2011) suatu perusahaan yang mengetahui hal tersebut, tentu tidak hanya menjual produk itu sendiri, tetapi juga kualitas dari produk tersebut dimana pada akhirnya hal tersebut membantu perusahaan untuk meningkatkan penjualan karena akan berpengaruh pada keputusan pembelian yang dilakukan oleh konsumen. Dari penelitian yang telah dilakukan sebelumnya, maka dalam penelitian ini diusulkan hipotesis sebagai berikut:

H3: kualitas produk berpengaruh positif terhadap keputusan pembelian

\section{Kerangka Pemikiran}






\section{METODE}

Populasi dan Metode Pemilihan Sampel. Aritonang (2007) mendefinisikan bahwa populasi merupakan keseluruhan unsur yang menjadi subjek penelitian. Populasi dalam penelitian ini adalah semua mahasiswa/i yang membeli produk Planet Popcorn di Fakultas Ekonomi Universitas Tarumanagara, Jakarta.

Metode pemilihan sampel yang digunakan dalam penelitian ini adalah nonprobability sampling, dimana diharapkan dari sampel yang dipilih dapat mencapai tujuan dari penelitian ini. Teknik ini digunakan atas dasar unsur kemudahan jangkauan populasi dan atas kemudahan dalam pengumpulan datanya untuk dijadikan sampel dan setiap sampel memiliki kesempatan yang sama untuk dipilih.

Dalam hal ukuran sampel, peneliti mengacu pada pendapat Malhotra (dalam Aritonang, 2007), ukuran sampel dapat didasarkan pada rata-rata ukuran sampel yang digunakan dalam studi-studi sejenis. Berdasarkan uraian di atas, pengambilan sampel yang dipilih adalah sebanyak 100 mahasiswa Fakultas Ekonomi Universitas Tarumanagara yang membeli produk Planet Popcorn.

Metode Pengumpulan Data. Metode pengumpulan data dalam penelitian ini menggunakan metode kuesioner (angket). Kuesioner adalah suatu teknik pengumpulan data yang dilakukan dengan cara memberikan seperangkat pertanyaan atau pertanyaan tertulis pada responden untuk menjawab.

Teknik Analisis Data. Pengujian Asumsi Klasik. Tujuan dari pengujian asumsi klasik adalah agar dapat menghasilkan nilai parameter yang baik sehingga hasil penelitian dapat lebih diandalkan. Pengujian gejala penyimpangan dari asumsi klasik perlu dilakukan untuk mengetahui sifat dari data sehingga dapat ditentukan jenis uji yang tepat untuk menganalisis hubungan antar variabel-variabel yang diteliti. Pengujian asumsi klasik dalam penelitian dapat dilakukan dengan bantuan SPSS 21 (statistical package for social science).

Analisis Regresi Ganda. Analisis regresi dilakukan bila hubungan dua variabel berupa hubungan kausal atau fungsional. Analisis regresi digunakan apabila kita ingin mengetahui bagaimana variabel dependen / criteria dapat diprediksikan melalui variabel independen secara individual.

Persamaan regresi dalam penelitian ini adalah untuk mengetahui seberapa besar pengaruh variabel independen atau bebas yaitu Brand Image (X1), Brand Awareness (X2), dan Kualitas Produk (X3) terhadap Keputusan Pembelian (Y) produk Planet Popcorn. Adapun bentuk persamaan regresi linier berganda yang digunakan dalam penelitian ini sebagai berikut :

$$
\mathrm{Y}=\mathrm{a}+\mathrm{b} 1 \cdot \mathrm{X} 1+\mathrm{b} 2 \cdot \mathrm{X} 2+\mathrm{b} 3 \cdot \mathrm{X} 3+\mathrm{e}
$$

Keterangan :Y = Keputusan Pembelian; a = Konstanta; b1,b2,b3 = Koefisien Regresi; X1 = Brand Image; X2 = Brand Awareness; X3 = Kualitas Produk; e = Faktor Gangguan

Teknik Pengujian Hipotesis. Setelah persamaan regresi didapat, maka tahap berikutnya yaitu melakukan pengujian hipotesis penelitian unuk mengetahui apakah variabel Brand Image, Brand Awareness, dan Kualitas Produk (Variabel Independen) dapat digunakan untuk memprediksi variabel Keputusan Pembelian (Variabel Dependen). Pengujian 
hipotesis tersebut dilakukan dengan uji statistik menggunakan uji F (secara keseluruhan) dan uji t (secara parsial).

\section{HASIL DAN PEMBAHASAN}

Hasil Pengujian Pre-test. Untuk mendukung pengerjaan di dalam kuesioner maka peneliti melakukan pengujian terlebih dahulu untuk mengetahui apakah kuesioner yang dipakai peneliti valid dan reliabel atau tidak. Berikut adalah hasil pre-test peneliti yang mengambil data responden sebanyak 30 orang.

Tabel 1. Uji Validitas Pre-test Brand Image

\begin{tabular}{ccc}
\hline Pertanyaan & Corrected-item total correlation & Keterangan \\
\hline 1 & 0,600 & Valid \\
2 & 0,511 & Valid \\
3 & 0,579 & Valid \\
\hline
\end{tabular}

a. Sumber: output SPSS

b. Valid jika $>0,361$ (Sugiyono, 2009)

Tabel 2. Uji Validitas Pre-test Brand Awareness

\begin{tabular}{ccc}
\hline Pertanyaan & Corrected-item total correlation & Keterangan \\
\hline 1 & 0,659 & Valid \\
2 & 0,558 & Valid \\
3 & 0,495 & Valid \\
\hline
\end{tabular}

a. Sumber : output SPSS

b. Valid jika $>0,361$ (Sugiyono, 2009)

Tabel 3. Uji Validitas Pre-test Kualitas Produk

\begin{tabular}{ccc}
\hline Pertanyaan & Corrected-item total correlation & Keterangan \\
\hline 1 & 0,692 & Valid \\
2 & 0,499 & Valid \\
3 & 0,581 & Valid \\
\hline
\end{tabular}

a. Sumber: output SPSS

b. Valid jika $>0,361$ (Sugiyono, 2009)

Tabel 4. Uji Validitas Pre-test Keputusan Pembelian

\begin{tabular}{ccc}
\hline Pertanyaan & Corrected-item total correlation & Keterangan \\
\hline 1 & 0,507 & Valid \\
2 & 0,567 & Valid \\
3 & 0,514 & Valid \\
\hline
\end{tabular}

a. Sumber : output SPSS

b. Valid jika $>0,361$ (Sugiyono, 2009)

Tabel di atas, menunjukkan hasil pengujian validitas untuk variabel brand image, brand awareness, kualitas produk, dan keputusan pembelian. Dapat dilihat bahwa butir 
pertanyaan memiliki nilai corrected item lebih besar dari 0,3494 sehingga semua butir pertanyaan dinyatakan valid.

Tabel 5. Uji Reliabilitas Pre-test

\begin{tabular}{clcc}
\hline No & \multicolumn{1}{c}{ Variabel } & $\begin{array}{c}\text { Alpha } \\
\text { Cronbach's }\end{array}$ & Keterangan \\
\hline 1 & Brand Image & 0,738 & Reliabel \\
2 & Brand Awareness & 0,740 & Reliabel \\
3 & Kualitas Produk & 0,757 & Reliabel \\
4 & Keputusan Pembelian & 0,708 & Reliabel \\
\hline
\end{tabular}

a. Sumber : output SPSS

b. Reliabel jika $>0,7$ (Aritonang, 2007)

Tabel di atas, menunjukkan hasil pengujian reliabilitas, dapat dilihat bahwa hasil perolehan Cronbach's Alpha untuk semua variabel lebih besar dari 0,7 sehingga semua butir pertanyaan dinyatakan reliabel.

Uji Validitas dan Reliabilitas. Uji Validitas. Agar dapat dinyatakan valid maka pengujian validitas konvergen lebih besar atau sama dengan 0,2. Semakin tinggi korelasi antara skor suatu butir pertanyaan atas pernyataan dengan skor totalnya maka instrumen tersebut akan semakin valid (Rust dan Golombok dalam Aritonang, 2007).

Tabel 6. Hasil Uji Validitas Brand Image

\begin{tabular}{ccc}
\hline Pertanyaan & Corrected-item total correlation & Keterangan \\
\hline 1 & 0,479 & Valid \\
2 & 0,545 & Valid \\
3 & 0,564 & Valid \\
\hline
\end{tabular}

a. Sumber : output SPSS

b. Valid jika $>0,2$ (Aritonang, 2007)

Tabel di atas, menunjukkan hasil pengujian validitas untuk variabel brand image. Dapat dilihat bahwa butir pertanyaan memiliki nilai corrected item lebih besar dari 0,2 sehingga semua butir pertanyaan dinyatakan valid.

Tabel 7. Hasil Uji Validitas Brand Awareness

\begin{tabular}{ccc}
\hline Pertanyaan & Corrected-item total correlation & Keterangan \\
\hline 1 & 0,517 & Valid \\
2 & 0,613 & Valid \\
3 & 0,467 & Valid \\
\hline
\end{tabular}

a. Sumber : output SPSS

b. Valid jika $>0,2$ (Aritonang, 2007)

Tabel di atas, menunjukkan hasil pengujian validitas untuk variabel brand awareness. Dapat dilihat bahwa butir pertanyaan memiliki nilai corrected item lebih besar dari 0,2 sehingga semua butir pertanyaan dinyatakan valid. 
Tabel 8. Hasil Uji Validitas Kualitas Produk

\begin{tabular}{ccc}
\hline Pertanyaan & Corrected-item total correlation & Keterangan \\
1 & 0,542 & Valid \\
2 & 0,509 & Valid \\
3 & 0,536 & Valid \\
\hline
\end{tabular}

a. Sumber : output SPSS

b. Valid jika > 0,2 (Aritonang, 2007)

Tabel di atas, menunjukkan hasil pengujian validitas untuk variabel kualitas produk. Dapat dilihat bahwa butir pertanyaan memiliki nilai corrected item lebih besar dari 0,2 sehingga semua butir pertanyaan dinyatakan valid.

Tabel 9. Hasil Uji Validitas Keputusan Pembelian

\begin{tabular}{ccc}
\hline Pertanyaan & Corrected-item total correlation & Keterangan \\
\hline 1 & 0,557 & Valid \\
2 & 0,612 & Valid \\
3 & 0,512 & Valid \\
\hline
\end{tabular}

a. Sumber : output SPSS

b. Valid jika $>0,2$ (Aritonang, 2007)

Tabel di atas, menunjukkan hasil pengujian validitas untuk variabel keputusan pembelian. Dapat dilihat bahwa butir pertanyaan memiliki nilai corrected item lebih besar dari 0,2 sehingga semua butir pertanyaan dinyatakan valid.

Uji Reliabilitas. Pengujian Reliabilitas instrumen dilakukan dengan menggunakan Cronbach's Alpha. Data dinyatakan reliabel jika memiliki nilai Cronbach's Alpha > 0,7. Semakin tinggi nilai koefisien reliabilitas, maka akan semakin reliabel (Rust dan Golombok dalam Aritonang, 2007).

Tabel 10. Hasil Uji Reliabilitas

\begin{tabular}{clcc}
\hline No & \multicolumn{1}{c}{ Variabel } & Alpha Cronbach's & Keterangan \\
\hline 1 & Brand Image & 0,709 & Reliabel \\
2 & Brand Awareness & 0,711 & Reliabel \\
3 & Kualitas Produk & 0,710 & Reliabel \\
4 & Keputusan Pembelian & 0,734 & Reliabel \\
\hline
\end{tabular}

a. Sumber : output SPSS

b. Reliabel jika > 0,7 (Aritonang, 2007)

Tabel di atas, menunjukkan hasil pengujian reliabilitas, dapat dilihat bahwa hasil perolehan Cronbach's Alpha untuk semua variabel lebih besar dari 0,7 sehingga semua butir pertanyaan dinyatakan reliabel.

Uji Normalitas. Pendeteksian ada atau tidaknya dapat dilihat pada tampilan grafik normal P-Plot of Regression Standarized. Jika datar menyebar di sekitar garis diagonal dan mengikuti arah garis diagonal maka model regresi memenuhi asumsi normalitas. Jika data 
menyebar menjauh dari garis diagonal dan tidak mengikuti arah garis diagonal maka model regresi tidak memenuh asumsi normalitas.

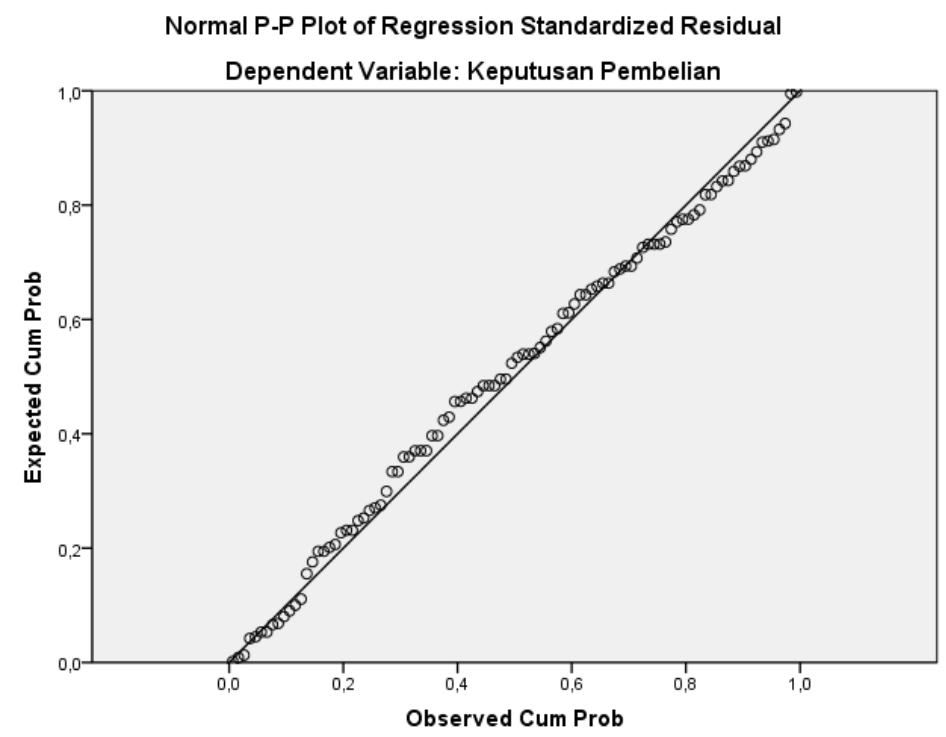

Gambar 2. Normal P.P. Plot of Regression

Tampilan Gambar 2 menunjukkan bahwa data terkontribusi secara normal karena titiktitik menyebar di sekitar garis diagonal dan mengikuti arah garis diagonal sehingga model regresi memenuhi asumsi normalitas.

Uji Multikolinearitas. Pendeteksian ada tidaknya multikolinearitas didasarkan pada besarnya Variance Inflation Factor (VIF), yaitu suatu estimasi besarnya multikolinearitas yang dapat meningkatkan varian pada suatu koefisien estimasi sebuah variabel penjelas. Jika Nilai VIF dalam suatu model regresi tidak lebih besar dari 10, maka tidak terdapat multikolinearitas.

Tabel 11. Uji multikolinearitas

\begin{tabular}{lcc}
\hline & Collinearity Statistic \\
\hline \multicolumn{1}{c}{ Model } & Tollerance & VIF \\
X1 (Brand Image) & 0,375 & 2,663 \\
X2 (Brand Awareness) & 0,412 & 2,429 \\
X3 (Kualitas Produk) & 0,424 & 2,360 \\
\hline
\end{tabular}

Tabel 11 menunjukkan bahwa nilai VIF ketiga variabel tidak lebih dari 10 sehingga tidak terdapat multikolinearitas.

Uji Heteroskedastisitas. Dalam model regresi yang baik tidak terdapat heteroskedastisitas. Pendeteksian ada atau tidaknya heteroskedastisitas dapat dilihat melalui data yang ada pada scatterplot. Jika titik-titik menyebar di atas dan di bawah angka 0 pada sumbu $\mathrm{Y}$, maka tidak terdapat heteroskedastisitas. 




Gambar 3. Scatterplot

Gambar 3 menunjukkan bahwa titik-titik menyebar di atas dan di bawah angka 0 pada sumbu Y, maka dapat disimpulkan tidak terdapat Heteroskedastisitas. Jadi persamaan regresi ganda tersebut layak untuk menganalisis data karena dalam regresi ganda tersebut terdapat normalitas, tidak terdapat multikolinearitas, dan tidak terdapat heteroskedastisitas.

Pengujian Hipotesis. Untuk mengetahui pengaruh brand image, brand awareness, dan kualitas produk terhadap keputusan pembelian maka peneliti menggunakan analisis regresi ganda. Analisis regresi ganda digunakan untuk mengetahui dua atau lebih variabel independen terhadap variabel dependen. Dalam hal ini variabel independennya adalah Brand Image (X1), Brand Awareness (X2), dan Kualitas Produk (X3). Variabel dependennya adalah Keputusan Pembelian (Y). Untuk mengetahui apakah terdapat tidaknya pengaruh secara signifikan kualitas pelayanan terhadap kepuasan maka dilakukan pengujian sebagai berikut :

Uji-t. Hasil analisis pengujian secara parsial (uji-t) dapat dilihat pada Tabel di bawah ini:

\begin{tabular}{|c|c|c|c|c|c|c|}
\hline & \multicolumn{6}{|c|}{$\begin{array}{l}\text { Tabel 12. Uji t } \\
\text { Coefficients }^{\mathbf{a}}\end{array}$} \\
\hline \multirow{2}{*}{\multicolumn{2}{|c|}{ Model }} & \multicolumn{2}{|c|}{$\begin{array}{l}\text { Unstandardized } \\
\text { Coefficients }\end{array}$} & \multirow{2}{*}{$\begin{array}{c}\begin{array}{c}\text { Standardized } \\
\text { Coefficients }\end{array} \\
\text { Beta }\end{array}$} & \multirow[b]{2}{*}{$\mathrm{t}$} & \multirow[b]{2}{*}{ Sig. } \\
\hline & & B & Std. Error & & & \\
\hline 1 & (Constant) & ,022 & 813 & & ,027 & 979 \\
\hline & X1 (Brand Image) & ,333 & 105 & ,300 & 3,178 & ,002 \\
\hline & X2 (Brand Awareness) & ,222 & 091 & ,221 & 2,455 & 016 \\
\hline & X3 (Kualitas Produk) & 425 & 096 & 393 & 4,420 & ,000 \\
\hline & $\begin{array}{l}\text { Dependent Variable: Ke } \\
\text { Signifikan jika < 0,05 }\end{array}$ & embelian & & & & \\
\hline
\end{tabular}


Dari Tabel 12 dapat dirumuskan persamaan regresi berganda adalah $\mathrm{Y}^{\prime}=0,022+0,333$ $X_{1}+0,222 X_{2}+0,425 X_{3}$. Penjelasan atas persamaan tersebut adalah sebagai berikut :

1) Jika $X_{1}$ (brand image), $X_{2}$ (brand awareness), dan $X_{3}$ (kualitas produk) $=0$ maka $Y$ (keputusan pembelian) sebesar 0,022.

2) Jika terjadi perubahan $X_{1}$ (brand image) sebesar satu satuan dan $X_{2}, X_{3}$ dianggap konstan maka Y (keputusan pembelian) akan bertambah sebesar 0,333 satuan.

3) Jika terjadi perubahan $\mathrm{X} 2$ (brand awareness) sebesar satu satuan dan $\mathrm{X}_{1}, \mathrm{X}_{3}$ dianggap konstan maka Y (keputusan pembelian) akan bertambah sebesar 0,222 satuan.

4) Jika terjadi perubahan $X_{3}$ (kualitas produk) sebesar satu satuan dan $X_{1}, X_{2}$ dianggap konstan maka Y (keputusan pembelian) akan bertambah sebesar 0,425 satuan.

Dari persamaan regresi di atas dapat disimpulkan bahwa variabel kualitas produk merupakan dimensi yang paling berpengaruh terhadap keputusan pembelian lalu diikuti oleh variabel brand image dan brand awareness.

Uji Parsial. Pengaruh brand image terhadap keputusan pembelian (H1). Dari Tabel 12 dapat dilihat bahwa brand image terhadap keputusan pembelian mempunyai nilai signifikan sebesar 0,002 <0,05 $(\alpha)$. Artinya H0 ditolak, maka dapat disimpulkan bahwa terdapat pengaruh signifikan antara variabel brand image (X1) terhadap keputusan pembelian (Y).

Pengaruh brand awareness terhadap keputusan pembelian (H2). Dari Tabel 12 dapat dilihat bahwa brand awareness terhadap keputusan pembelian mempunyai nilai signifikan sebesar 0,016 0,05 $(\alpha)$. Artinya H0 ditolak, maka dapat disimpulkan bahwa terdapat pengaruh signifikan antara variabel brand awareness (X2) terhadap keputusan pembelian (Y).

Pengaruh kualitas produk terhadap keputusan pembelian (H3). Dari Tabel 12 dapat dilihat bahwa kualitas produk terhadap keputusan pembelian mempunyai nilai signifikan sebesar 0,000 < 0,05 $(\alpha)$. Artinya H0 ditolak, maka dapat disimpulkan bahwa terdapat pengaruh signifikan antara variabel kualitas produk (X3) terhadap keputusan pembelian $(\mathrm{Y})$.

\section{Uji-F (uji pengaruh secara simultan)}

Tabel 13. Uji -F

\begin{tabular}{llrrrrr}
\multicolumn{7}{c}{ ANOVA $^{\mathbf{b}}$} \\
\hline Model & & Sum of Squares & df & Mean Square & F & \multicolumn{1}{c}{ Sig. } \\
\hline 1 & Regression & 358,450 & 3 & 119,483 & 67,736 &, $000^{\mathbf{a}}$ \\
& Residual & 169,340 & 96 & 1,764 & \\
& Total & 527,790 & 99 & & & \\
\hline
\end{tabular}

a. Predictors: (Constant), Kualitas Produk, Brand Awareness, Brand Image

b. Dependent Variable: Keputusan Pembelian

Dari uji F pada Tabel 13, di dapat F-hitung sebesar 67,736 dengan tingkat signifikansi 0,000 . Nilai probabilitas $(0,000)$ lebih kecil dari $(<) 0,05$ sehingga H0 ditolak yang artinya paling sedikit terdapat satu variabel yang mempengaruhi keputusan pembelian. 
Pembahasan. Berdasarkan tabel 4.16, didapat persamaan regresi sebagai berikut :

$$
\mathrm{Y}^{\prime}=0,022+0,333 \mathrm{X}_{1}+0,222 \mathrm{X}_{2}+0,425 \mathrm{X}_{3} \text {. }
$$

Artinya: (1) Jika X1 (brand image), X2 (brand awareness), dan X3 (kualitas produk) $=0$ maka Y (keputusan pembelian) sebesar 0,022; (2) Hasil perhitungan yang diperoleh nilai regresi 0,333 yang berarti bahwa brand image memiliki pengaruh yang signifikan dan positif terhadap keputusan pembelian. Semakin baik brand image yang diberikan oleh Planet Popcorn akan menaikkan keputusan pembelian dari Planet Popcorn; (3) Hasil perhitungan yang diperoleh nilai regresi 0,222 yang berarti bahwa brand awareness memiliki pengaruh yang signifikan dan positif terhadap keputusan pembelian. Semakin baik brand awareness yang diberikan oleh Planet Popcorn akan menaikkan keputusan pembelian dari Planet Popcorn; (4) Hasil perhitungan yang diperoleh nilai regresi 0,425 yang berarti bahwa kualitas produk memiliki pengaruh yang signifikan dan positif terhadap keputusan pembelian. Semakin baik kualitas produk yang diberikan oleh Planet Popcorn akan menaikkan keputusan pembelian dari Planet Popcorn.

Hasil penelitian ini sesuai dengan penelitian yang dilakukan oleh Sulistyawati (2011) yaitu "Analisis Pengaruh Citra Merek dan Kualitas Produk terhadap Keputusan Pembelian Laptop Merek Acer di Kota Semarang” bahwa terdapat pengaruh signifikan citra merek dan kualitas produk terhadap keputusan pembelian. Hal ini menandakan bahwa semakin baik citra merek dan kualitas produk yang dibuat dan diberikan ke konsumen, akan membuat konsumen semakin loyal terhadap suatu produk. Dan sebaliknya apabila citra merek dan kualitas produk yang diberikan sedikit akan membuat konsumen menjadi tidak loyal.

Hasil penelitian ini sesuai dengan penelitian yang dilakukan oleh Nigam dan Kaushik (2011) tentang “ Impact of Brand Equity on Customer Purchase Decisions: An Empirical Investigation with Special Reference to Hatchback Car Owners in Central Haryana". Penelitian ini menemukan bahwa brand awareness (kesadaran merek) mempengaruhi keputusan pembelian. Hal ini menandakan bahwa semakin tinggi kesadaran yang diberikan maka konsumen akan melakukan pembelian produk. Dan sebaliknya semakin rendah kesadaran yang diberikan maka konsumen tidak akan melakukan pembelian produk.

\section{PENUTUP}

Simpulan. Dari hasil analisis bab IV, maka dapat diambil kesimpulan sebagai berikut: (1) Terdapat pengaruh variabel brand image terhadap keputusan pembelian yang dilakukan oleh mahasiswa/i pembeli Planet Popcorn di Universitas Tarumanagara. Hal ini terlihat dari tingkat signifikansi sebesar 0,002 (lebih kecil dari 0,05); (2) Terdapat pengaruh variabel brand awareness terhadap keputusan pembelian yang dilakukan oleh mahasiswa/i pembeli Planet Popcorn di Universitas Tarumanagara. Hal ini terlihat dari tingkat signifikansi sebesar 0,016 (lebih kecil dari 0,05); (3) Terdapat pengaruh variabel kualitas produk terhadap keputusan pembelian yang dilakukan oleh mahasiswa/i pembeli Planet Popcorn di Universitas Tarumanagara. Hal ini terlihat dari tingkat signifikansi sebesar 0,000 (lebih kecil dari 0,05).

Saran. Terkait dengan penelitian ini, peneliti akan memberikan beberapa saran yang sekiranya dapat bermanfaat bagi perusahaan dan bagi peneliti lain, yaitu sebagai berikut: (1) Bagi perusahaan, peneliti menyarankan agar sebaiknya perusahaan meningkatkan brand image dan brand awareness dan sebaiknya perusahaan lebih memperhatikan hasil 
akhir dari produk tersebut, karena variabel brand image, brand awareness, dan kualitas produk berpengaruh terhadap keputusan pembelian mahasiswa/i pembeli Planet Popcorn di Universitas Tarumanagara. Apabila perusahaan meningkatkan brand image dan brand awareness dan terus melakukan peningkatan kualitas produk maka konsumen akan semakin loyal dan puas yang nantinya akan berdampak juga pada citra perusahaan dan peningkatan pendapatan perusahaan. (2) Bagi peneliti lain, disarankan untuk menambah variabel independen lainnya yang juga diperkirakan dapat mempengaruhi variabel dependen yaitu keputusan pembelian seperti brand loyalty, perceived quality, dan brand associations. (Nigam dan Kaushik, 2011)

\section{DAFTAR RUJUKAN}

Aaker, A.D. (2008) Manajemen Ekuitas Merek. Alih bahasa oleh Aris Ananda. Jakarta: Mitra Utama.

Ambadar, J., Abidin, M., Isa, Y. (2007) Mengelola Merek. Jakarta: Bina Karsa Mandiri.

Arafat, Wilson. (2006) Behind A Powerful Image: Menggenggam Strategi dan Kuncikunci Sukses Menancapkan Image Perusahaan yang Kokoh. Yogyakarta : Penerbit Andi.

Aritonang R, Lerbin R. (2007) Riset Pemasaran. Bogor: Ghalia Indonesia.

Belch, George E. (2004) Advertising and Promotion: An Integrated Marketing Communications Perspective. Edisi ke-6. New York: Mc Graw-Hill Company.

Ghozali, Imam. (2010) Aplikasi SPSS. Semarang: Badan Penerbitan Universitas Diponegoro.

Griffin, Ricky W, Ronald J Ebert. (2006) Pengantar Bisnis. 8th Edition. Jakarta: Erlangga.

Kotler, Philip and Kevin Lane Keller. (2006) Marketing Management. 12th edition. New Jersey : Pearson Education, Inc.

Kotler, Philip dan Gary Armstrong. (2008) Prinsip-prinsip Pemasaran. 12th Edition. Jakarta: Erlangga.

Laksana, Fajar. (2008) Manajemen Pemasaran. Yogyakarta: Graha Ilmu.

Priyatno, Dwi. (2010) Teknik Mudah dan Cepat menganalisis Data Penelitian Dengan SPSS. Yogyakarta: Gaya Media.

Schiffman, G Leon \& Kanuk, L. Leslie. (2004) Consumer Behavior. 7th Edition. Upper Saddle River: Prentice Hall International, Inc

Shimp, Terence A. (2010) Advertising, Promotion, and Other Aspect of Intergrated Marketing Communications. Edisi 8. USA : South-Western Cengage Learning

Sugiyono. (2009). Metode Penelitian Bisnis (MPB). Jakarta: Alfabeta.

Sulistyawati, Praba. (2011) Analisis Pengaruh Citra Merek dan Kualitas Produk terhadap Keputusan Pembelian Laptop Merek Acer di Kota Semarang. Jurnal Bisnis dan Manajemen.

Suryani, Tatik. (2008) Perilaku Konsumen: Implikasi pada Strategi Pemasaran. Edisi 1. Yogyakarta: Graha Ilmu. 